\title{
USING OPERATION TECHNIQUE TO TEACH SPEAKING OF PROCEDURE TEXT
}

\author{
Hamid Darmadi ${ }^{1}$, Sudarsono $^{2}$, Regina ${ }^{3}$ \\ ${ }^{1}$ Master Study Program of English Language Education, ${ }^{2}$ Tanjungpura University, \\ ${ }^{3}$ Tanjungpura University \\ correspondence email: kinderstudent@gmail.com
}

\begin{abstract}
The research was aimed to examine the operation technique to improve teaching speaking in a procedure text. The research was Classroom Action Research in three cycles. The participants of the research were year 11 students of SMK AlMadani Pontianak who had difficulties in speaking skills, especially in performing spoken texts in a procedure text. The data were divided into qualitative and quantitative data. The qualitative data were collected by using questionnaires, video recordings, observation sheets, observation's checklists, student's selfevaluation, and field notes. Meanwhile, the quantitative data were collected from the student's performance tests. The finding showed that through operation, the student's learning behavior changed positively from less to good. The writer concludes that the use of operation technique which is adjusted to the classroom's condition improve teaching speaking in a procedure text as well as the student's speaking skill in performing the procedure text.
\end{abstract}

Keywords: Classroom Action Research, Speaking Skill, Procedure Text, Operation.

\begin{abstract}
Abstrak
Penelitian ini bertujuan untuk menguji teknik operasi untuk meningkatkan pengajaran berbicara dalam teks prosedur. Penelitian ini adalah Penelitian Tindakan Kelas dalam tiga siklus. Partisipan dalam penelitian ini adalah siswa kelas 11 SMK Al-Madani Pontianak yang mengalami kesulitan dalam keterampilan berbicara, terutama dalam melakukan teks lisan dalam teks prosedur. Data dibagi menjadi data kualitatif dan kuantitatif. Data kualitatif dikumpulkan dengan menggunakan kuesioner, rekaman video, lembar observasi, daftar periksa observasi, evaluasi diri siswa, dan catatan lapangan. Sementara itu, data kuantitatif dikumpulkan dari tes kinerja siswa. Temuan menunjukkan bahwa melalui operasi, perilaku belajar siswa berubah secara positif dari kurang menjadi baik. Penulis menyimpulkan bahwa penggunaan teknik operasi yang disesuaikan dengan kondisi kelas meningkatkan pengajaran berbicara dalam teks prosedur serta keterampilan berbicara siswa dalam melakukan teks prosedur. Kata kunci: Penelitian Tindakan Kelas, Keterampilan Berbicara, Teks Prosedur, Operasi.
\end{abstract}




\section{INTRODUCTION}

English is taught for a specific purpose in vocational high schools in Indonesia. To master English well, the student must be competent in one of the language skills. One of them is speaking. There are various ways for learners to be competent in English (Richard 2008). To be skilled in speaking, for example, the student needs to practice daily communications in various settings. It seems fair to assume that speaking skill plays a large part in this overall competence.

Prior to the actual research, the writer had conducted a pre-observation as a teacher at SMK Al-Madani Pontianak. The pre-observation figured out that student there had difficulties in speaking skills, especially in performing spoken texts. One of the possible factors included the student's learning interest and study preparation. The students were also not confident to perform their English orally. Furthermore, the students seemed to have a lack of practice to the English conversation as well as involvement in using the target language. In the Indonesian curriculum, it is important for the students to be able to speak in English because it is one of the targets of teaching English in vocational high schools. Moreover, the English language is one of the subjects that is tested in the National Exam. In addition, English is also considered important when studying computer as their major course. The language used in the computer is mainly the English language, including parts of computer. For these reasons, the student's problem regarding English language in the classroom must be solved.

Several studies were conducted on the issue of solving the poor skill of speaking (e.g. Azadi, Aliakbari, \& Azizifar 2015). They applied various teaching techniques or activities through classroom interaction. They reported that these techniques improved the speaking skill of EFL students in their classrooms. They investigated Iranian learners studying English as a foreign language. Like Indonesia, English serves as a compulsory subject in Iran's educational systems. However, speaking has not received much attention in the final examination rather than other skills. Their data then showed that there was a positive and significant relationship between classroom interaction and improving speaking proficiency. As a result, classroom interaction can be considered as a way of improving learners' speaking ability.

In Indonesia, Hadijah (2015) recently studied another collaborative technique that may improve speaking skills. It was called class wide peer tutoring (CWPT). This technique was used by Siti at SMK Labor Pekanbaru to improve the students' speaking skill. With this technique, students could help their peers and work collaboratively to solve a problem. 
They also had to prepare themselves with learning materials related to the topics before they performed in front of the classroom. As a result, Hadijah claimed that the average score of her students for speaking skills improved.

Amrullah (2016) also investigated students' speaking ability through a task-based learning approach. He revealed that the use of task-based learning improved the students' speaking ability. He conducted a study on a task-based learning approach where it had a variety of activities and challenges which required the students to think independently and improve their capabilities.

In addition, Tuncel (2015) also mentioned that one of the important factors in speaking learning process was self-confidence. He added that there was a relationship between selfconfidence with achievement, especially communicative competence.

The present research then highlights some points that there were various ways to implement the speaking activity in the classroom. However, teachers should choose an activity that is well related to the topic and objective of the lesson. The teacher also must consider the classroom situation, the student's conditions, and materials that will be taught to the students. As a teacher, the writer should find an effective way to teach speaking for his class at SMK Al-Madani Pontianak.

Many experts said that teaching speaking is very important. Luoma, for instance, (2005) argued that speaking skill was an important part of the curriculum in language teaching and this made them an important object of assessment as well. Richard (2008) claimed that learners may apply various techniques to study English. In order to develop their proficiency in speaking, it depends on the functions of speaking that might differ from one and the other, some individuals may learn the language for daily communications while some others are willing to pass an English language test (i.e. students). Those are just a few reasons why people need to master speaking and then it seems fair to assume that speaking skills play a large part in this overall competence besides listening, writing, and reading.

The teacher should consider some competencies for speaking. These competencies will distinguish between speaking skills and other skills in English. Linguistic theory has suggested linguistic competence and linguistic performance. Speaking is one of the linguistic performances that should be acquired by people both for individual needs and for social life. Harmer (2005) explained that the ability to speak fluently was not only to know the language features, but also the ability to process information and language appropriately. He defined competence as to when to and not to speak as well as a competence of what to talk about, with whom, when, where, and in what manner. Based 
on the explanation, the importance of speaking is often related to the speech act and sociocultural features that we can develop for our speaking appropriateness in people's communities such as conducting and interpreting our social life. We are able to recognize or judge our hearer identity and personality once we begin to interact and have a conversation with him/her. Moreover, Luoma (2005) set out that on the basis of what people hear, they made some tentative and possibly subconscious judgments about the speaker's personality, attitudes, home region, native/non-native, and someone's status. The writer concludes that one of the important skills that should be acquired and assessed in a meaningful way for the students is speaking. One of the speaking functions is as a meaningful interaction. The participants of speaking consist of the speaker and the listener. Both of them are constructing and sharing the event together. They have the right influence which can be social's need or individual's need. For example, when a man and a lady meet at the bus as passengers. Both of them can talk related to their interests. The man could start to talk about the weather those days as his motives, while the lady could respond and implied the man with some issues of the weather or even give her social experience about it. The communication competences are developing deeper then.

For EFL students, speaking is communication. "Speaking is one of the four macro skills necessary for effective communication in any language, particularly when speakers are not using their mother tongue" (Boonkit, 2010). In the writer's perception, communication should be promoted through some ways in the real situation of the international community or with native speakers. One of the ways is through some beneficial teaching techniques for teaching speaking. The writer also considers some problems and factors that should be solved. Boonkit (2010) concluded in his study that confidence, the creativity of topics, and speaking competence were the key aspects to improve speaking. In some cases, most EFL students are afraid of making mistakes when talking to their teachers or their friends. Moreover, their friends tended to laugh at him/her (Khan \& Ali, 2010). Derakhsan, Khalili, \& Beheshti, (2016) posited that there were three important factors that influenced learner's speaking competence such as cognitive factors, linguistic factors, and affective factors. Grammar and vocabulary were included in cognitive factors. Then, in linguistic factors, the important features of learner's oral proficiency were pronunciation, grammar, and vocabulary. Finally, the student's anxiety and self-restriction were considered to be effective factors.

Considering the essential role of speaking skills, the writer assumes that it is necessary for teachers to find out a technique in order to create a situation that leads the students to 
consider that learning is enjoyable and interesting. There are a lot of speaking activities that can lead the students to oral practices.

Harmer (2005) mentioned that acting from a script, communication games, discussion, prepared talks, questionnaires, simulation, and role play as some of the techniques to teach speaking in English language. Those activities can be used by teachers to teach speaking for communication purposes. Teachers could ask students to perform the text as if they were doing it in real life. Alternatively, the students could act the texts out in front of the class as themselves. These activities could be used as a way to measure how far students could speak, say, and express their feeling in English.

Silberman (1996) mentioned one of the active learning strategies was by using silent demonstration. The purpose of a silent demonstration is to teach step by step of a procedure by demonstrating silently. The teacher demonstrated how to do something without any explanation while the students were paying attention. Then, the teacher asked them to work in pairs to follow and explain the demonstration sequentially.

There were interesting communication techniques called Operation proposed by Clark (1980). In this case, the writer was interested in the operation technique to teach speaking which was considered suitable for teaching procedure texts. The writer was strongly sure that the research would be different when using the operation technique to teach speaking through procedure text rather than using other techniques for communicative competences.

Zakia (2015) had studied the effect of role-playing technique for speaking skill and it already survived into modern days. The writer believed that the operation technique would do the same. Some revise and adaptation needed to make operation became effective activity nowadays.

According to Winters \& Nelson (1993) operation is a procedure for doing something, using a natural sequence of events. Clark, (1980) also stated that operation is an activity to introduce vocabulary and practice grammatical constructions (especially verb phrases) in the context of a natural or logical sequence of actions.

There were three types of operation mentioned by Winters \& Nelson (1993). They were operations by a piece of equipment, by skills development, and by involving body movement. Examples of each type included how to operate a tape recorder, how to fold the clothes, and how to greet the teacher properly or how to eat properly in a restaurant. Operation technique has some advantages that are suitable for the student's need in this research context. Winters \& Nelson (1993) explained the benefit of using operation for the students in the classroom. First of all, it is an effective way for students to actively use the 
language in a purposeful and functional manner. Second, the technique is very useful for teaching and practicing verb tenses. After that, it can be designed around the student's specific needs. Then, it adds a variety to the classroom so as the students may enjoy doing them. Finally, it can also be used as supplementary activities when working on intonation and stress patterns, vocabulary building, cultural information, word order, possessive pronouns, locative phrases, or adverbs.

This research, thus, considers the fifth benefit as the main rationale to investigate the operation technique because it is capable of improving the student's speaking ability where larger attention shall be paid onto the intonation and stress patterns of presenting the procedural steps. The writer specifically investigates to what extent the operation technique may improve the student's speaking ability. It might be one of the effective ways for EFL students who try to develop their communication skills. In addition, the technique is hoped to be effective for the students at SMK Al-Madani Pontianak to improve their speaking skill. From those advantages, the writer strongly chose the operation technique to be applied in this research. The technique was designed for intermediate levels such as senior high school students or vocational high school students because the technique was suitable to teach procedure text which explained how to do something through a logical sequence of actions. Procedure text is one of the lessons stated in the syllabus of senior or vocational high school levels especially in year 11 .

Even though some research has been reported to teach procedure text in undergraduate students' level, there seemed no researcher who used the operation as his/her technique to improve student's speaking ability.

There was a similarity between simulation, role-play, demonstration, and operation. All of those techniques used oral performance proficiency. However, the writer believes that operation has a different way to perform or practicing the sequence of actions, because the teacher should be the model to perform first and doing such a repetitive way to explain his actions and speaks to be remembered by the students.

The writer interested in operation techniques regarding the fact of how speaking ability can be improved through procedure text. In the writer's opinion, operation has an important process in completing the sequence of language into action. Operation should be one of the techniques that allow the students to use the language in a spoken text and verbally respond in a physical way to the teacher's instruction. The writer finally chose operation technique in his research which he also experiences to taught procedure text at 
his vocational high school for year 11 . The research was hopefully different from another usage of teaching techniques to improve student's speaking ability.

As mentioned earlier, the students are still struggling in using English in the classroom. The research question of the research is "How does operation technique improve teach speaking of procedure text to year 11 (TKJ 1) students of SMK Al-Madani Pontianak in academic year 2018/2019?" The research question were specified into (a) How does operation technique improve students' learning behavior in teaching speaking of procedure text to years 11 (TKJ 1) students of SMK Al-Madani Pontianak? and (b) How does operation technique improve the student's performance in speaking of procedure text? Meanwhile, the purpose of the research is to investigate whether or not operation technique may improve the student's speaking ability in the procedure text.

\section{RESEARCH METHOD}

The present research was conducted using Classroom Action Research (CAR). The design was used to study classroom activities while teaching speaking to year 11 students of SMK Al-Madani Pontianak. Burns (2010) explained that Action Research was a deliberative way to bring changes and a better improvement in the practice of teachinglearning from the problematic situation that the participants consider into more deeply and systematically. Therefore, action research was typically designed and conducted by practitioners who analyzed the data to improve their own actual happen of practice into ideal ones. In specific, Hopkins (2008) defined that classroom action research is a research design in which teachers look critically at their own classrooms and use research primarily for the purpose of improving their teaching and the quality of education in their schools.

Classroom action research has potentially generated genuine and sustained improvements in schools. It gives the teacher new opportunities to reflect on and assess their teaching, to explore and test new ideas, methods and material, to assess how effective the new approaches were, to share feedbacks with fellow team members and to make decisions about which approaches to include in the team's curriculum, instruction, and assessment plans. Classroom Action Research also can be applied in almost any setting where a problem involving people, tasks and procedures carried out for a solution, or where some change of feature results in a more desirable outcome (Cohen, Manion, \& Morrison (2005).

In this research, the writer applied classroom action research adapted from Kemmis and Mc.Taggart (cited in Burns 2010). The phase of the research covered (1) Plan where the writer worked together with a collaborator to plan and focus on solving research 
questions. Following this, the writer made guidance to start the research and prepared the material based on the student's need. The writer planned when it shall be completed and concerned the setting/situation. In this phase, the writer also prepared some instruments such as questionnaires, syllabus, learning materials, lesson plans, and tests. (2) Action where served as the implementation of the plannings made in the previous phase. The writer presented learning materials for students in the classroom. The writer also recorded the data by using a videotape. (3) Observe where the writer collaborated with two collaborators to observe the teaching-learning process. Both were English teachers at the school from different grades. The first collaborator observed and took notes on everything happened in the classroom using a field note and an observation checklist. The second collaborator recorded classroom activities and ensured that the recording data could run well. and (4) Reflect where the writer and the collaborator analyzed, synthesized, interpreted and evaluated the information which was obtained from the classroom observation. The data included recorded data and notes which were taken by the collaborator. This phase was carried out after the teaching and learning process. The result of the reflection phase was treated to determine what should be done in the first cycle and plan for the next cycle if necessary. Reflection is the process of evaluating the changes occur to the students, teacher and learning activity. The teacher and the observer discussed the result of the observation and evaluated the treatment and the students' achievement in the cycle. The writer planned a new activity that may overcome the problems that still appear in the first cycle in the classroom. The writer put the plan in action for the next cycle and stop the cycle in the third cycle for the final result.

This research involved 35 students who were currently studying at year 11 at SMK Al-Madani Pontianak. They studied in class XI majoring in TKJ 1. The participants were selected because they were considered familiar with the procedure text since they used to study the text type in year 10. Nevertheless, the student remained to face difficulties in year 11 when their teacher found that many students in the class were still not able to speak fluently and confidently. They were also reported to have a lack of vocabulary stocks and unable to apply English grammar properly. There were also two students with a disability. Further, the majority of the students rarely used English inside and outside classroom activities and tended to speak with a low voice. They were also reported to make some errors in pronunciation and sentence structures.

In this study, there were two kinds of data, namely: qualitative and quantitative data. Qualitative data were obtained as the primary data from non-number or descriptive 
data. The data was taken from an observation sheet of student's learning behavior, observation checklists, and field notes. They described the actual process of pre-activity, whilst-activity, and post-activity of the teaching and learning process. It also referred to the use of percentages of the student's achievement in performing their speaking skills. Then, quantitative data were obtained from the result of the test and used as qualitative data. The quantitative data were presented in the form of table. There were three kinds of the raw scores which were obtained for the quantitative data such as questionnaires of preliminary study; percentage for showing the student's learning behavior in speaking English from cycle 1 until cycle 3, and scores showing the student's mean score of the performance test in speaking from the cycle 2 and cycle 3.

Class Observation was used by the writer to collect the data. Class Observation is the action applied by the writer and his collaborators to watch the subject of the research carefully in order to notice things that have a connection with the problems in the classroom. In this study, the writer acted as the teacher. The observation was carried out by the collaborators by using observation sheets through a video recording, observation checklists, and field notes. The students were requested to work in a pair to discuss and perform the procedure text in front of the classroom.

Creswell (2012) elaborated that there are 4 ways to collect qualitative data. The writer used an observation form for the research by using observation sheets of student's learning behavior, hand phone's video recorder, observation checklists, and field notes. Before the study, the second collaborator controlled the class and put the video recorder in the class to record the learning process. The video recording used to help the writer and collaborators to reflect any missed data or to see student's learning behavior or participation in performing speaking operation using the procedure text. The collaborators recorded the student's activity and put the scale in observation sheet for the first, second, and third cycles to indicate the category. The collaborators also checked the teaching-learning process by using an observation checklist and put positive or negative marks during the observations by using field notes.

The writer analyzed data obtained from two kinds of data. The qualitative data were described from the reflection phase of the research from all cycles and the quantitative data were gathered from the result of student's performance tests in cycle 2 and cycle 3. According to Creswell (2012), there were six steps in analyzing and interpreting qualitative data. The qualitative data followed the steps such as organizing the data, exploring the data, describing the data into text data, transcribing the data into themes, and interpreting the 
data into some aspects with scale. As a result, the data described what happened while in the teaching process, behavior changes, the distractions, and what should be evaluated in the next cycle.

In analyzing the data, the writer organized the data separated from field notes and the video recording of the research. The writer and collaborators described the observation from the video recording and also from the field notes into typed/text data. The writer also developed themes from the data into more specific for the answer to the research questions. The writer decided and divided the theme for his research into a major theme and a minor theme. The major theme came from the most problematic scheme that the writer solved and related to the research questions. In this case, the major themes were the student's behavior and the student's structures. The minor themes were the student's setting, student's processes, and student's activities.

Then the writer interpreted the data and separated them into five aspects so that the data became easies to organize. The aspects included settings (seating, class preparation, student attendance); student's perspectives (student's self-confidence); processes (distraction from the classmate); activities (situation and student's attention); and structures (Student's use of content, vocabulary, language use, pronunciation). The aspects were identified for the major and minor theme of the problematic situation that the student and the teacher had in the classroom before. After that, the writer explored the data and created scales. In developing the scales, the writer measured the activity of the students and categorized it based on the scales. It was adapted from the Likert Scale. The scale was numbered from one to three with the description from less-moderate-mostly.

Finally, the writer described the process of how operation technique was successful to improve the students' ability in speaking in every cycle by using percentage. The writer described the percentage of the students who felt enthusiast, motivated and confident to speak in each cycle. In conclusion, the writer created a comparison table of learning behavior improvement in every cycle equipped with its percentages and mean scores. In quantitative data, there were also 4 aspects that the students should perform which covered vocabulary, language use, pronunciation, and self-confidence. The quantitative data supported by the students' mean score improvements of each cycle in research that show the significance of the students' mean score in the second and third cycles. Before finding the mean score, the writer gave score for each student who performed in front of the class by considering some specifications for each aspect. After that, to find individual scores in the performance test, the total scale for each aspect was converted to the actual score. At 
last, the scale was converted to real scores and find the level of each students speaking ability. Finally, the writer provided the mean score from the sum of all students' individual scores of performance test divided by the total maximum score for all aspects. The writer compared the student's average score in the performance test for cycle 2 and cycle 3 and decide the final result of student's improvement in speaking.

\section{FINDINGS AND DISCUSSION}

\section{Findings}

The data presented in the study were obtained from the implementation of the classroom action research which covered the students' learning behavior before the implementation of operation technique, during the implementation of the action and their performance test toward their speaking ability through procedure text in Cycle 1, Cycle 2 and Cycle 3. There was one meeting for each in cycle 1 and cycle 2 while cycle 3 comprised of two meetings. The learning behavior which the writer considered for the findings were classified into five aspects such as student's setting during the class, student's perspectives, student's processes, student's activities, and student's structures. The writer described the student's condition in the video from the chosen sample of most active to the least active students in the classroom participation. The writer took 5 pairs of students. The findings described to answer the research questions, how the student's participated during the teaching-learning process when using operation, and the problems found during the class to get the primary and the secondary data.

The first cycle was conducted by observing five aspects of the student's behavior in the classroom during the teaching and learning process. The result of the student's learning behavior was described by using a scale. Table 1 below showed the aspect with its scale.

Table 1. Observation Sheet of Student's Learning Behavior in Cycle 1

\begin{tabular}{|c|c|c|c|}
\hline Aspects & Specification & Scale & Description \\
\hline \multirow{3}{*}{ Student's Setting } & Seating & 2 & Normal seat applied \\
\hline & $\begin{array}{l}\text { Class } \\
\text { Preparation }\end{array}$ & 2 & $\begin{array}{l}\text { There were some students } \\
\text { who were still outside the } \\
\text { classroom }\end{array}$ \\
\hline & $\begin{array}{l}\text { Student } \\
\text { Attendance }\end{array}$ & 2 & Only one student was absent \\
\hline Student's Perspectives & Self-Confidence & 2 & $\begin{array}{l}\text { Some of the students felt not } \\
\text { confidence to perform as a } \\
\text { model in front of the class. }\end{array}$ \\
\hline Student Processes & Distractions & 2 & $\begin{array}{l}\text { There were few students who } \\
\text { came late to the class }\end{array}$ \\
\hline Student's Activities & $\begin{array}{l}\text { Student's } \\
\text { Attention }\end{array}$ & 2 & $\begin{array}{l}\text { The majority of the students } \\
\text { paid attention to the teaching- }\end{array}$ \\
\hline
\end{tabular}




\begin{tabular}{llll}
\hline Aspects & Specification & Scale & Description \\
\hline Student's Structures & Activeness & 2 & $\begin{array}{l}\text { learning process, only 2 } \\
\text { people who sometimes still } \\
\text { had chatting while the teacher } \\
\text { was explaining the lesson. }\end{array}$ \\
\hline Content & 2 & $\begin{array}{l}\text { Some of the students were still } \\
\text { silent. }\end{array}$ \\
\hline Vocabulary & 1 & $\begin{array}{l}\text { Most of the student still } \\
\text { practiced without mentioning } \\
\text { the goal or materials }\end{array}$ \\
\hline Language Use & 1 & $\begin{array}{l}\text { Some of the students found a } \\
\text { lot of difficult words. }\end{array}$ \\
\hline Pronunciation & 1 & $\begin{array}{l}\text { Most of the students could not } \\
\text { identify action verbs and } \\
\text { temporal conjunctions }\end{array}$ \\
\hline
\end{tabular}

The table illustrated that the minimum scale achieved by the students in the setting was 2 . It means that the setting belongs to the moderate category because almost all students get involved. Next, scale 2 as the moderate category was also given to the students who got involved in the student's perspectives, process, and activities. The total was only 6 for all three activities. It was because some of the students did not involve in the discussion because they did not know how to respond to it. Some students were not ready to perform the procedure text in front of the class.

Moreover, scale 1.5 was given to the students which could not complete almost whole activities in structures. Some students felt confused to do the next instructions from the teachers. Several students were not really interested in the whole activity. Some of the activities were also not done well. There were four activities that several students did not do. The first problem was some of the pairs had difficulties in matchmaking his/her action with their friend's instruction. Some of them had a lack of self-confidence and tended to feel nervous so that

They forgot to ask another and pretended to skip the action. Another problem was that other students seemed not to pay more attention to what their friend's performance. It was because most of the students still didn't have a lot of vocabulary to respond to their friends who performed in front of the class. Some of them also had low responses to answer his/her friends who asked about his/her procedure because they were still confused about what should they do next. Therefore, in the next cycle, the writer tried to find any strategies to overcome the problems. 
In conclusion, the obtained total scale for the students' involvement in Cycle 1 was 19 and then was divided by the maximum total scale 33 then multiplied $100 \%$. As a result, the percentage of the students' participation during the teaching and learning activities in Cycle 1 was $57 \%$.

The primary data for qualitative data in the second cycle was conducted by observing the five aspects of student's behavior in the classroom during the teaching and learning process. The result of the student's learning behavior was described by using Scale. Table 2 below showed the aspect with its scale.

Table 2. Observation sheet of student's learning behavior in Cycle 2

\begin{tabular}{|c|c|c|c|}
\hline Aspects & Specification & Scale & Description \\
\hline \multirow[t]{3}{*}{ Student's Setting } & Seating & 1 & Normal seat applied \\
\hline & Class Preparation & 3 & $\begin{array}{l}\text { All students were already in } \\
\text { the class }\end{array}$ \\
\hline & $\begin{array}{l}\text { Student } \\
\text { Attendance }\end{array}$ & 3 & $\begin{array}{l}\text { All students attended the } \\
\text { class }\end{array}$ \\
\hline Student's Perspectives & Self-Confidence & 3 & $\begin{array}{l}\text { Almost all students were } \\
\text { ready to perform in front of } \\
\text { the class including the two } \\
\text { disability students }\end{array}$ \\
\hline Student's Processes & Distractions & 2 & $\begin{array}{l}\text { There was one student who } \\
\text { tried to adapt the learning } \\
\text { because of his absence from } \\
\text { the previous meeting and did } \\
\text { not have a partner to discuss } \\
\text { with. There were also two } \\
\text { students who sometimes had } \\
\text { to chat with another }\end{array}$ \\
\hline \multirow[t]{2}{*}{ Student's Activities } & $\begin{array}{l}\text { Student's } \\
\text { Attention }\end{array}$ & 2 & $\begin{array}{l}\text { Almost all the students were } \\
\text { paying attention to the } \\
\text { teaching-learning process. }\end{array}$ \\
\hline & Activeness & 1 & $\begin{array}{l}\text { In the whilst-activity and in } \\
\text { the discussion, a few of them } \\
\text { were getting bored. However, } \\
\text { in the post-activity, almost all } \\
\text { students enjoyed the learning } \\
\text { process while the rest were } \\
\text { still confused. }\end{array}$ \\
\hline \multirow[t]{2}{*}{ Student Structures } & Content & 3 & $\begin{array}{l}\text { Most of the student } \\
\text { mentioned the goal and } \\
\text { materials }\end{array}$ \\
\hline & Vocabulary & 3 & $\begin{array}{l}\text { Only a few students still had } \\
\text { difficulties in using } \\
\text { appropriate vocabulary }\end{array}$ \\
\hline
\end{tabular}




\begin{tabular}{llcl}
\hline Aspects & Specification & Scale & Description \\
\hline Language Use & 2 & $\begin{array}{l}\text { Almost all of the students } \\
\text { could use appropriate action } \\
\text { verbs and temporal } \\
\text { conjunctions and used the } \\
\text { present tense. }\end{array}$ \\
\hline Pronunciation & 2 & $\begin{array}{l}\text { Some of the students were } \\
\text { still misspelled the words }\end{array}$ \\
\hline
\end{tabular}

The minimum scale achieved by the students in setting and activeness was 1 . It meant that the setting belongs to the less category because some of the students who sat in the back remained silent, had a chatting, did nothing, or even did the lazy thing with their friend while the rest in the front seat got involved. Several students were reluctant to do the discussion since they got bored with the activity and a few of them were not really interested in the whole activity. Next, scale 2 referred to the moderate including in student's distraction, attention, language use, and pronunciation. It was because, in the discussion, there was one student who still adapted to the learning process because he was absent in the previous meeting. He also didn't have a partner to discuss their procedure texts. Almost all the student paid attention while only a few of them still confused and had a lack of responses to the discussion.

In Student structures, only a few students didn't use appropriate action verbs, temporal conjunctions, and present tense. Some of them needed more practice and attention in the classroom, especially in using correct pronunciations. Moreover, scale 3 as the good category was given to class preparation, attendance and self-confidence, content, and vocabulary because all students could get in the class on time, all 35 students attended the meeting and all of them involved in performing the procedure text in front of the class. It was given to the students who completed the whole activity. While in content, the schematic structures of procedure text were completely mentioned and only several students still had difficulties in choosing appropriate vocabulary.

In general, most of the activities were almost carried out. There were some students who couldn't change their vocabulary because they didn't want to find the meaning by using a dictionary or asking the teacher. Some of them also could not practice the procedure text in pairs because it took time for them to memorize the steps.

e-ISSN: 2089-2810

p-ISSN: 2407-151X 
In conclusion, the obtained total scale for the students' involvement in Cycle 2 was 25 and then divided by the maximum total scale 33 then multiplied $100 \%$. As a result, the percentage of the students' participation during the teaching and learning activities in Cycle 2 was $76 \%$.

For the quantitative data, there were 4 aspects that scored by the teacher or the writer. They were vocabulary, language use, pronunciation, and self-confidence. The maximum score for each aspect was 25. After the total score of each individual student found, the writer counted the mean score for Cycle 2. Overall, the data showed that the average of the student's score was 62.7 which means good. In the individual score, there were some students who still got low scores among others. For example, 4 students in the test had score 3 in Vocabulary, 3 students had 2 in Language Use, 1 student had 1 in Pronunciation, and 2 students had 1 in Self-Confidence.

The third cycle was conducted in two meetings. The primary data for the third cycle in the first meeting was conducted by observing the five aspects of student's behavior in the classroom during the teaching and learning process. The result of the student's learning behavior was described by using Scale. Table 3 below showed the aspect with its scale.

Table 3. Observation sheet cycle 3 first meeting

\begin{tabular}{|c|c|c|c|}
\hline Aspects & Specification & Scale & Description \\
\hline Student Setting & Seating & 3 & $\begin{array}{l}\text { Using a modified seat to } \\
\text { prevent students from } \\
\text { getting bored and help them } \\
\text { focus. }\end{array}$ \\
\hline & Class Preparation & 3 & $\begin{array}{l}\text { The teacher set the } \\
\text { preparation in advance } \\
\text { before the teaching-learning } \\
\text { process began. }\end{array}$ \\
\hline & Student Attendance & 3 & All the students came in. \\
\hline Student's Perspectives & Self-Confidence & 2 & $\begin{array}{l}\text { Some of them performed in } \\
\text { a low-tone voice in front of } \\
\text { the class. }\end{array}$ \\
\hline Student's Processes & Distractions & 2 & $\begin{array}{l}\text { Some of the students did } \\
\text { not focus on learning and } \\
\text { bothered other pairs. }\end{array}$ \\
\hline Student's Activities & Student's Attention & 2 & $\begin{array}{l}\text { Most students paid attention } \\
\text { to the teaching-learning } \\
\text { process, but some of them } \\
\text { still had a chat while other } \\
\text { pairs were performing in } \\
\text { front of the class. }\end{array}$ \\
\hline Student's Structures & Activeness & 3 & $\begin{array}{l}\text { All of the students were } \\
\text { actively participating. }\end{array}$ \\
\hline
\end{tabular}




\begin{tabular}{llcl}
\hline Aspects & Specification & Scale & Description \\
\hline Content & 2 & $\begin{array}{l}\text { Only a few of them still } \\
\text { performed procedure texts } \\
\text { without mentioning the } \\
\text { goal. }\end{array}$ \\
\hline Language Use & 3 & $\begin{array}{l}\text { Almost all students } \\
\text { enriched their vocabulary. }\end{array}$ \\
\hline Pronunciation & 1 & $\begin{array}{l}\text { Almost all students used } \\
\text { action verbs and temporal } \\
\text { conjunctions in their } \\
\text { procedure texts. }\end{array}$ \\
\hline & 1 & $\begin{array}{l}\text { Some of the students were } \\
\text { still misspelled the words }\end{array}$ \\
\hline
\end{tabular}

The minimum scale achieved by the students was only in pronunciation i.e. 1. It means that they belong to the "less category" because half of the students were still misspelled. Next, scale 2 as the moderate category was also given to the students who got involved in self-confidence, distractions, student's attention, and content. It is because some of the students performed the procedure text in a low-tone voice which indicated not confident conduct. Some of them even bothered other pairs by borrowing things or materials for them. They also chatted with their friends while the rest gave bad comments about other pair's performance or preparation. Some of them were nervous to perform in front of the class. One student was not ready to perform with her pair because she was absent from the previous meeting. However, scale 3 was given to all students because they fully come into the class without absence and some of them were very interested and enthusiastic in waiting for their turn to perform in front of the class. They were put in a new seating strategy to avoid them from not focused.

The teacher and the students set their preparation in the class well. They already studied at home to enrich their vocabulary and used language use appropriately. All of the activity was almost done. However, few of them sometimes forgot to mention the goal of the procedure text. Some of them were busy to memorize the steps rather than paying attention to their friends who performed in front of the classroom. It means some of them were not ready yet to perform. Overall, Most of the students successfully followed the activity from the beginning until the end.

Overall, the obtained total scale for the students' involvement in Cycle 3 first meeting was 27 and then it was divided by the maximum total scale 33 then multiplied $100 \%$. As a result, the percentage of the students' participation during the teaching and learning activities in the first meeting of Cycle 3 was $82 \%$.

e-ISSN: 2089-2810 
The primary data for the third cycle in the second meeting was conducted and the result of the student's learning behavior was described by using Scale. Table 4 below showed the aspect with its scale.

Table 4. Observation Sheet of Student's Learning Behavior in Cycle 3

Second Meeting

\begin{tabular}{|c|c|c|c|}
\hline Aspects & Specification & Scale & Description \\
\hline \multirow[t]{3}{*}{ Student Setting } & Seating & 3 & $\begin{array}{l}\text { Using a modified seat to } \\
\text { prevent students from getting } \\
\text { bored and help them focus. }\end{array}$ \\
\hline & Class Preparation & 3 & $\begin{array}{l}\text { The teacher set the } \\
\text { preparation in advance before } \\
\text { the teaching-learning process } \\
\text { began. }\end{array}$ \\
\hline & Student Attendance & 2 & $\begin{array}{l}\text { Not all the students came into } \\
\text { the class. }\end{array}$ \\
\hline $\begin{array}{l}\text { Student's } \\
\text { Perspectives }\end{array}$ & Self-Confidence & 3 & $\begin{array}{l}\text { There were no students who } \\
\text { were not able to perform in } \\
\text { front of the class. Their voices } \\
\text { were clear. }\end{array}$ \\
\hline Student's Processes & Distractions & 3 & $\begin{array}{l}\text { The rest of the students } \\
\text { remained silent when waiting } \\
\text { for their turn. }\end{array}$ \\
\hline \multirow[t]{2}{*}{ Student's Activities } & Student's Attention & 2 & $\begin{array}{l}\text { All students paid attention to } \\
\text { the teaching-learning process. } \\
\text { Only a few of them still } \\
\text { whispered to chat with others } \\
\text { while the other pairs were } \\
\text { performing in front of the } \\
\text { class. }\end{array}$ \\
\hline & Activeness & 2 & $\begin{array}{l}\text { Some of the students did not } \\
\text { actively participate because } \\
\text { they had finished presenting } \\
\text { their tasks. }\end{array}$ \\
\hline \multirow[t]{4}{*}{ Student's Structures } & Content & 3 & $\begin{array}{l}\text { All students performed a } \\
\text { procedure text by mentioning } \\
\text { the performance's goals, } \\
\text { materials, and steps. }\end{array}$ \\
\hline & Vocabulary & 3 & $\begin{array}{l}\text { Almost all students enriched } \\
\text { their vocabulary. }\end{array}$ \\
\hline & Language Use & 3 & $\begin{array}{l}\text { Almost all students used } \\
\text { action verbs and temporal } \\
\text { conjunctions in their } \\
\text { procedure text. }\end{array}$ \\
\hline & Pronunciation & 2 & $\begin{array}{l}\text { Only a few students have still } \\
\text { misspelled the words }\end{array}$ \\
\hline
\end{tabular}


There was no minimum scale founded by the students. Scale 2, as the moderate category, was only given to the students in student's activeness and pronunciation. It was because some of the students could not participate in the class because they had finished performing their tasks. To avoid these students creating problems such as making noise and disturbing other's students, the teacher asked them to read in the library. Only few students have still misspelled the words because these students did not do adequate practice at home. Scale 3 was given to almost all categories where the students fully came into the classroom without absence. They were very interested and enthusiastic in waiting for their turns to perform in front of the class. They were put in the same seating as before. The teacher and the students set their preparation in the class well. They already studied at home to enrich their vocabulary and used the language appropriately. They only chatted by whispering with their friends when necessary because they wanted to focus on their preparation before performing in front of the classroom. In addition to this, all students bravely performed in front of the class, even the 2 students who had a disability also performed confidently. Almost all of the students paid attention to the content, vocabulary, language use and pronunciation. All of the activities were completely done.

The obtained total scale for the students' involvement in the second meeting of Cycle 3 was 29 and then it was divided by the maximum total scale 33 then multiplied $100 \%$. As a result, the percentage of the students' participation during the teaching and learning activities in the second meeting of Cycle 3 was $89 \%$.

In the first and second test for the quantitative data, the teacher asked the student to perform their procedure text by using the real things that they brought from home. The students seemed very enthusiast and felt passionate. However, they were too loud to perform so that the class situation became crowded. There were 4 aspects that were scored by the writer. They were vocabulary, language use, pronunciation, and self-confidence. The maximum score for each aspect was 25. After finding the total score of each individual student, the writer found the mean score for Cycle 3 first meeting. However, because the time was over, the performance test continued to the second meeting. In the second meeting, some strategies were used to overcome the previous situation which was too loud and crowded so that not all students were in the class. Only the rest of them who didn't perform in the first meeting got in the class while the others were waiting for their turn. The teacher asked the students who had performed to make a video about their procedure texts in the library. Based on the result, the average score was 71.00 which meant good. However, the result of the second test was better than the previous one. There were only e-ISSN: 2089-2810 
two aspects which were really hard to gain more. It was language use and pronunciation. It needed more practice and time to make them better. There were also 2 students who got a low score. The reason is that they had a special treatment to take care of.

The writer and the collaborators decided to stop the test because there was an improvement rather than before.

\section{Discussion}

In Cycle 1, the most frequent problem that happened was about the student's interest in learning procedure text through operation technique. In the questionnaire, $70 \%$ of students seemed uninterested with the operation technique because they had to demonstrate the procedure text in English. Most of them liked to speak in English but they felt unconfident. Moreover, they also had difficulties in speaking because of their lack of using language use, vocabulary, and pronunciation.

In Cycle 2, the teacher helped the student by having them work in pairs and letting them choose their own procedure text. Then the teacher guided them to make a procedure text with common use vocabulary, using appropriate language use, and the teacher asked them to speak by using correct pronunciation. The teacher also asked them to practice in front of the class for their self-confidence. As a result, the writer found that there was an improvement in their learning behavior and their results in the performance test. Nevertheless, some of them still needed more help.

In Cycle 3, the teacher and the collaborators still found several students who had difficulties in pronunciation and self-confidence. It was because they needed special treatment, disabled students. One of them was unable to listen and talk clearly while the second one needed more repetitions to be focused. Even though, they showed a lot of changing in the third cycle because they were better than the previous cycles. They believed that they had their confidence. Sometimes the teacher repeated the misspelled words for them who still needed help in pronunciation before or after the performance test. Furthermore, the students were more active and tended to make noises and disturbed other students. The teacher and the collaborator discussed to avoid these problems later in the second meeting by excluding the students who were already done the performance to read in the library, while the rest of the students who didn't perform were still in the class. The distractions from the students were decreased.

All students could finish their performance and the teacher finally gave a chance to all students if they wanted to share their difficulties during the teaching-learning process. e-ISSN: 2089-2810 
The teacher also concludes the materials before the class ended. After analyzing the process of all cycles and finding the result, the writer and the collaborators decided to stop the actions and the data showed an indicator of success.

The complete first data in Cycle 1, 2, and 3 in Table 5 showed that the students' improvement in learning behavior successfully described in all 5 aspects through the percentage with its description. The aspects were about student's setting, student's processes, student's perspectives, student's activities, and student's structures.

To sum up, the percentage of the students' improvements in each cycle was $57 \%$, $76 \%$, and $85 \%$. Thus, the final percentage for the students' improvement during the teaching-learning process using operation in all cycles was $76 \%$ (good). It means that the criteria of success obtained from the observation sheets have been achieved.

In analyzing the second data, the writer counted the student's results in a performance test from cycle 2 and cycle 3 for its mean score. The research findings showed that the student's mean score in the second cycle was 62.7. It was qualified into "good" criteria. The writer had to think a better preparation for the next cycle. In the third cycle, the student's mean score was 71.0. It was also qualified into "good" criteria. Certainly, there was an improvement because the students who got a high score could share their knowledge and helped other students by discussing it after the lesson.

Table 5. Summary of the Students' Improvement in All Cycles.

\begin{tabular}{clccl}
\hline Cycle & \multicolumn{1}{c}{ Focus } & $\begin{array}{c}\text { Number of } \\
\text { Aspects }\end{array}$ & Percentage & Description \\
\hline 1 & Operation Activity & 5 & $57 \%$ & Less \\
\hline 2 & Operation Activity \& Structures & 5 & $76 \%$ & Good \\
\hline 3 & $\begin{array}{l}\text { Operation Activity \& Performance } \\
\text { Test }\end{array}$ & 5 & $82 \%$ & Very Good \\
\hline 3 & $\begin{array}{l}\text { Operation Activity \& Performance } \\
\text { Test }\end{array}$ & 5 & $89 \%$ & Very Good \\
\hline Average & & $76 \%$ & Good \\
\hline
\end{tabular}

In conclusion, the findings were satisfying. The student's ability in speaking was improved by using the operation technique through procedure text. In the teaching-learning process, the modified operation technique was not only to ask the students to perform the procedure text, but it also made the students felt confident to speak in English. The use of real things in performing the text also made the students could see and feel the real situation 
in performing procedure text using operation technique. Then, the prediction of the action hypotheses was accepted.

\section{CONCLUSIONS}

Based on the discussion in the previous chapter, the writer can conclude that the use of operation technique in teaching speaking through procedure text in this study shows an improvement in students' learning behaviors. The data revealed an increase during the first cycles of the last cycles. In Cycle 1, for instance, $57 \%$ of the students followed the activity with five aspects which did not meet the criteria of success yet. Then, it turned into 76\% and had met the criteria of success in Cycle 3 where averagely raised into $85 \%$ of the students who followed the activity.

The use of operation technique in teaching speaking through procedure text also showed an improvement in the student's achievement results, in particular, the performance test. In cycle 2, the mean score was 62.7 and it turned into 71.0 in cycle 3. It means that the criteria for both scores were "good". The use of operation technique was able to help the students in speaking skills. With the teacher assistance or guidance, it can help the students in using a common vocabulary, using appropriate language use, practicing to pronounce, and motivating the students to be confident. The use of real things in operation techniques

had given the students chances to perform speaking in more understandable manner through the process. The learning activity also had given them an opportunity to prepare everything for making a good procedure text in terms of content and grammar.

From preliminary observation until the third cycle, their perception of speaking activities was not really positive. Several of the students still did not like speaking because pronouncing words was considered difficult for them. It needed a lot of practice and exposure. However, in Cycle 2 and Cycle 3, they were more confident and enjoyable in speaking and felt that the performance was interesting.

\section{REFERENCES}

Amrullah. 2016. Improving English Speaking Through Task-Based Learning Approach. TESOL Indonesia International Conference (pp. 101-108). Lombok: English Language Education Publishing.

Azadi, S., Aliakbari, M., \& Azizifar, A. 2015. The Role of Classroom Interaction on Improvement of Speaking Among Iranian EFL Learners. International Journal of Language Learning and Applied Linguistics World, 126-135.

Boonkit, K. 2010. Enhancing the development of speaking skills for non-native speakers of English. Procedia Social and Behavioral Sciences, 1305-1309. 
Burns, A. 2010. Doing Action Research in English Language Teaching. New York: Taylor annd Francis.

Clark, R. C. 1980. Language Teaching Techniques. Vermont: Pro Lingua Associates.

Cohen, L., Manion, L., \& Morrison, K. 2005. Research Methods in Education (5th ed.). London: Routledge Falmer.

Creswell, J. W. 2012. Educational Research (4th ed.). Boston: Pearson Education.

Derakhsan, A., Khalili, A. N., \& Beheshti, F. 2016. Developing EFL Learner's Speaking Ability, Accuracy and Fluency. English Language and Literature Studies, 177-186.

Hadijah, S. 2015. Improving Students' Speaking Skill through Classwide Peer Tutoring (CWPT) at Grade Ten of Accounting 2 at SMK Labor Binaan FKIP UNRI Pekanbaru. International Seminar on English Language and Teaching, 424-429.

Harmer, J. 2005. The Practice of English Language Teaching. New York: Longman.

Hopkins, D. 2008. A Teacher's Guide to Classroom Research (4th ed.). New York: Open University Press.

Khan, N., \& Ali, A. 2010. Improving the Speaking Ability in English: The Students' Perspective. Procedia Social and Behavioral Science 2, 3575-3579.

Luoma, S. 2005. Assessing Speaking. Cambridge: Cambridge University Press.

Richard, J. C. 2008. Teaching Listening and Speaking. New York: Cambridge University Press.

Silberman, M. L. 1996. Active Learning. Massachusettes: Allyn and Bacon.

Tuncel, H. 2015. The Relationship between Self-Confidence and Learning Turkish as a Foreign Language. Educational Research and Reviews, 2575 - 2589.

Winters, T. A., \& Nelson, G. L. 1993. Operation in English. Vermont: Pro Lingua Associates.

Zakia, R. 2015. The Effect of the Role-Play Technique on Improving EFL Learners' Speaking Skill. Algeria. 